\title{
A Current Status of Centers and Market for Hearing Aids in Korea
}

\author{
Sangik $\operatorname{Sim}^{1}$, Jinsook Kim ${ }^{1,2}$ \\ 'Department of Speech Pathology and Audiology, Graduate School, Hallym University, Chuncheon, Korea \\ ${ }^{2}$ Division of Speech Pathology and Audiology, Research Institute of Audiology and Speech Pathology, \\ College of Natural Sciences, Hallym University, Chuncheon, Korea
}

\section{국내 보청기 센터와 시장의 현황 연구}

\author{
심 상 익 $\cdot$ 김 진 숙,2
}

한림대학교 일반대학원 언어병리청각학과 ${ }^{1}$, 한림대학교 자연과학대학 언어청각학부 · 청각언어연구소 ${ }^{2}$

\begin{abstract}
Purpose: The purpose of this study was to analyze the current statuses of hearing aid centers and markets in Korea through surveys and to provide the element understanding about the basic structure of the hearing aid distribution. Methods: A survey was conducted with a questionnaire developed. A total of 30 items in six categories, basic situations of hearing aid center including scale and circumstances, opening motivation and handling brands, sales status, marketing promotion and opinions of the current hearing aid market. 114 responses were acquired and analyzed. Results: Any certificates for evaluation and rehabilitation of hearing aids were held by $74.6 \%$ of all participants. Among them, $67.5 \%$ have the audiological certificate presented by Audiological Testing Service, which is the main facility of the Korean audiologists who were educated properly. The average selling price of hearing aids was found to be around 1.5 million won. $34.2 \%$ of centers sold less than 10 units, while $21.1 \%$ sold more than 25 units monthly. $71.7 \%$ of the respondents answered that it is necessary to have an officially approved license for hearing aid sales. Also, it was pointed out that overheated price competition among centers was problem. Conclusion: This study broadened the understanding of Korean hearing aid centers and markets and provided the index for developing the hearing aid market-related policies. This kind of research should be carried out continuously to systematize the hearing aid market and resolve the emerging social problems of the people who use hearing aids such as the aged population.
\end{abstract}

Key Words: Hearing aid, Hearing aid center, Certificate for hearing aid, Hearing aid market.

\section{INTRODUCTION}

최근 우리나라의 여러 가지 사회적 당면 과제 중 크게 부각 되고 있는 사항은 저출산과 인구의 고령화로 인해 나타나는 사 회적인 문제이다. 우리나라의 인구 고령화는 2000년에 65세 이 상의 고령인구가 $7.2 \%$ 로 고령화 사회에 진입하였으며, 2018년에 $14.3 \%$ 로 고령 사회가 되었고, 2026년에는 21.6\%로 초고령화 사 회가 될 것으로 예측하고 있다(KOSIS, 2017). 이로 인해 발생되

(c) This is an Open Access article distributed under the terms of the Creative Commons Attribution Non-Commercial License (https://creativecommons.org/licenses/by-nc/4.0) which permits unrestricted non-commercial use, distribution, and reproduction in any medium, provided the original work is properly cited.
는 여러 가지 문제점 중 하나가 노화에 따른 노인성 난청의 증 가이다. 더욱이 제5기 국민건강영양평가 조사에서 65세 이상 인 구의 $30.6 \%$ 가 노인성 난청을 갖고 있다고 보고하여 노화에 따른 노인성 난청이 증가하고 있음을 시사하고 있다(KCDC, 2014). 따 라서 노인성 난청을 포함한 난청에 대한 적절한 대처법을 강구 하고 보건복지 지원 서비스 체계를 향상시키기 위해 국내 연령 별 난청 발생과 현황에 대한 이해의 필요성이 증가하였다. 더욱 이 노인성 난청의 경우 이를 대처할 수 있는 보장구로 인공 와 우는 그 시술 건수가 $10 \%$ 미만으로 매우 미미하여 보편적인 보 장구의 역할을 할 수는 없는 것으로 나타났다(MOHW, 2012). 따라서 비이식형 보청기가 대다수의 노인성 난청인이 착용하는 
일반적인 보장구로 추정할 수 있다. 그러나 보청기는 의료기기 판매업 신고만 하면 누구나 판매할 수 있어 정확한 유통과 보 급 현황에 대해 파악하기 어렵다. 더욱이 최근에 '보청기적합관 리'에 대한 내용을 한국표준으로 제정하여 국제표준(International Organization for Standardization)에 부합하는 표준화 된 청각 서비스 제공의 기틀을 마련하였으나(KEIT, 2019), 아직 국가 표준이 정착될 수 있는 지원 제도는 체계적으로 이루어지 지 않고 있다. 또한 판매 및 유통, 부실한 사후 서비스 체계, 보 장구 지원금의 비효율적 집행 등에 대한 문제는 여전히 잔존하 고 있다(BAI, 2018).

인구의 고령화로 보청기의 수요와 판매 수량은 꾸준히 성장하 는 추세를 나타내고 있다. 국내의 경우 국가기술표준원(Choi, 2017)의 보고서에 따르면 연간 보청기 판매 대수는 약 18 만 대로 추산하고 있다. 그러나 이 보고서는 국내 전체 39개소의 보청기 수입 및 제조회사 중 10개소의 현황을 조사한 자료로(Choi, 2017) 조사 범위가 제한적이고 보청기 판매유통이 최종적으로 이루어지는 보청기 센터나 이비인후과의 보청기 클리닉 등으로 부터 통합한 수치가 아니다. 더욱이 최근에는 보청기의 유통경 로가 대형 마켓이나 홈쇼핑으로도 확대되고 더 복잡해지는 양 상을 띄고 있어 국내 보청기 시장의 종합적인 규모를 파악하기 는 점점 어려워지고 있다.

미국과 유럽 등의 선진국에서는 보청기 시장의 유통구조와 보청기의 만족도와 관련된 체계적인 자료를 확보하기 위해 정 부 차원의 조사나 자격증 관리 기관과 청각 관련 산업협회에서 기금을 조성하여 통계를 축적하고 관련 자료를 확보하여 관리 하고 있다. 미국의 보청기 시장 및 만족도 조사 프로그램인 MarkeTrak 보고서는 1984년부터 현재까지 35년간 미국 내 청 각산업협회(Hearing Industry Association)가 기금을 조성하 여 미국의 보청기 시장 동향에 대한 조사 및 만족도 조사를 실 시하고 있는 대표적인 사례이다(Abrams \& Kihm, 2015). 유럽 과 일본의 경우도 유럽 보청기제조자협회(Europe Hearing Instruments Manufacturers Association, EHIMA)와 일본 보 청기제조자협회(Japan Hearing Instruments Manufacturers Association, JHIMA)가 주관하여 스위스의 시장 조사기관인 Anovum에 의뢰하여 보청기 시장과 관련된 현황을 3년 간격으 로 조사하여 EuroTrak 보고서를 발표하고 있다. EuroTrak은 2009년에 영국, 프랑스, 독일 3개국에서 시작한 이후 스위스, 이탈리아, 덴마크, 노르웨이, 폴란드, 네덜란드, 벨기에 등이 추 가적으로 참여하고 2012년에 일본이, 2018년에 인도가 합류하 여 총 12개국의 보고서로 자리 잡고 있다(EHIMA, 2019).

이들 보고서를 기반으로 볼 때 전 세계 보청기의 매출 규모 는 2013년 기준으로 전 세계 매출 중 미국이 약 $36 \%$, 독일이 약 $8 \%$, 일본이 약 $7 \%$ 로, 전 세계 매출의 절반 정도를 이 세 개의
국가가 차지하고 있는 것으로 나타났다. 구체적인 판매 수량을 살펴보면 미국의 연간 판매 수량은 2017년 기준 약 370만 대이 고, 매년 5 6\% 정도의 성장을 지속하고 있어 2019년에는 400만 대를 넘는 판매 수량을 기록할 것으로 예상하고 있고(Strom, 2018) 일본은 연간 판매 수량이 2012년에 50만 대를 넘었고 2017 년에 56만 대 이상의 보청기가 판매된 것으로 보고하였다(JHI$\mathrm{MA}, 2018) .2015$ 년에 발간된 한국보건산업 진흥원의 “보청기 국내외 시장분석”에서는 전 세계 보청기 평균 성장률을 $6.9 \%$ 로 보고하고 있다. 순위를 살펴보면 중국의 $18.3 \%$, 독일의 $10.3 \%$, 프랑스의 9.1\%에 이어 우리나라는 네 번째로 높은 $8.5 \%$ 의 성장 률로 나타났다(KHIDI, 2015).

보청기의 보급에 대한 정보는 보청기를 구매할 수 있는 센터 에 대한 현황과 보청기를 다루는 청각 전문가의 활동 정보로 미 루어 추정할 수 있다. 미국의 청능사(audiologist)는 약 12,250 명이고 보청기 판매자(hearing aid dispenser)는 약 5,570명으 로 이들이 청각 전문가로 활동하고 있다. 대부분 보청기 판매자 는 보청기 센터에 근무하지만 청능사는 청능 재활 전문가, 교육 기관의 교수, 병의원의 청력 평가 등 다양한 업무를 담당하고 있 으며 약 13,000여 개의 보청기 센터가 있다(Staab, 2015). 일본은 보청기 센터가 3,750개(JHIMA, 2018)이고 우리나라는 1,582개 의 보청기 센터가 신고되어 운영되고 있다(NHISS, 2018). 국내 의 자격증 현황은 청능사가 2,663 명, 보청기 관리사가 288 명, 청각사가 1,283명인 것으로 보고하였다(KAA, 2018).

인구의 고령화로 인해 노인성 난청자의 수가 증가함에 따라 대표적인 보장구인 보청기의 국내 시장도 꾸준히 증가하고 있 다. 그러나 아직 국내 보청기 시장에 대한 전체적인 규모, 판매 경로, 가격 및 서비스 체계, 청각 전문가의 활동 범위 등에 대한 조사는 미흡한 실정이다. 따라서 본 연구는 실질적으로 국내에 서 절반 이상의 보청기를 취급하는 보청기 센터를 대상으로 센 터 규모와 전문성, 월 판매 수량 및 가격대, 취급 브랜드 및 제 품, 주로 판매하는 보청기 타입 등에 관한 설문지 조사를 실시 하여 보청기 시장 현황을 분석하고자 하였다. 이를 통해 노인 성 난청에 도움을 줄 수 있는 보장구인 보청기에 대한 올바른 이해를 통해 국내 난청 관련 서비스 구조를 개선할 수 있는 방 법을 찾아보고자 한다. 더 나아가 난청 관련 산업을 발전시키 기 위해 보청기 시장 현황에 대한 조사의 필요성을 강조하고 선 진국형 난청과 보청기 관련 기초 조사 항목들에 대한 구체적 방향을 제시하고자 하였다.

\section{MATERIALS AND METHODS}

설문지는 구글 온라인 양식으로 배포하였으며 대상군은 세 개의 보청기 제조사의 대리점과 한국보청기협회 회원과 보청기 
센터를 중심으로 구성된 보청기 연구모임의 구성원들과 개별 센터의 보청기 취급 관련 청각 전문인들이었다. 총 응답자는 114 명이었는데, 이는 국민건강보험공단의 장애인보장구 업소로 등록된 1,587 개 보청기 센터 중 $7.2 \%$ 의 표본이고, 병의원, 약국, 의료기기 판매점, 안경점 등을 포함한 보청기를 취급하는 전체 장애인보장구 등록 업소 3,089 개 중 $3.7 \%$ 의 표본이다(NHISS, 2018).

각 나라별로 보청기 판매 자격, 보청기의 유통구조, 보청기 센 터의 시설 기준 등이 다르므로 외국의 설문지를 번역하여 사용 하기는 어려웠다. 따라서 국외의 설문조사들의 내용을 참고하여 국내 보청기 시장의 현황을 파악하는 데 필요한 범주(category) 와 항목(item)으로 본 연구에 사용된 설문지를 제작하였다. 설 문지는 6 개의 범주로 보청기 센터의 기본 조사 사항, 규모 및 시 설 환경 조사, 개설 동기와 자격증 및 취급 브랜드, 판매 현황 및 가격대 조사, 홍보 및 마케팅, 국내 보청기 시장의 성장에 대 한 견해로 구성하였다. 첫 번째 범주인 보청기 센터의 기본 현황 에 관한 질문에는 지역, 센터 형태, 보청기 센터 운영 경력, 인력 구조 등에 대한 질문으로 총 6개 항목으로 구성하였고, 두 번 째 범주는 우리나라 보청기 센터들의 시설적인 수준을 파악하 기 위해 센터의 크기, 보증금 및 월 임대료, 센터의 보유 장비 등에 대한 4개 질문 항목으로 구성하였고, 세 번째 범주는 보 청기 센터의 개설 동기와 취급하는 브랜드를 파악하고 해당 브 랜드를 취급하는 이유에 대해 질문하는 7개 항목으로 구성하 였고, 네 번째 범주는 센터당 월 평균 판매 수량과 판매 금액, 평 균 판매 단가, 주로 판매되는 보청기 형태 등에 대한 질문으로 7 개 항목으로 구성하였고, 다섯 번째 범주는 보청기 센터에서 홍 보 및 마케팅 수단으로 활용되는 매체와 홍보를 위해 지출되는 비용을 파악하는 질문으로 4개 항목으로 구성하였고, 여섯 번 째 범주는 국내 보청기 시장의 성장을 저해하는 요소와 성장과
활성화에 대한 견해를 묻는 2 개의 항목으로 구성하였다. 이와 같이 6개 범주의 총 30 개 항목으로 구성된 설문지로 연구를 진 행하였다(Appendix).

\section{RESULTS}

\section{기본 조사}

전체 응답자 중 99명(86.8\%)이 보청기 센터의 소유자였으며, 14명(12.3\%)이 보청기 센터 직원, 1 명(0.9\%)이 이비인후과 부설 보청기 센터 직원이었다. 응답자의 지역별 분포는 서울특별시가 30 명(26.3\%)으로 가장 많았으며, 경기도가 29명(25.4\%), 부산 광역시가 12명(10.5\%) 순이었다(Figure 1).

보청기 센터의 유형에 대한 질문에 104명(92.0\%)이 보청기만 취급하는 센터였고 의료기기 판매점의 매장 내 매장(shop in shop) 형태가 4명(3.5\%), 이비인후과 내 보청기 센터가 3명(2.7\%), 안경점 내 보청기 센터가 2명(1.8\%)이었다. 66명(57.9\%)이 보청 기 제조사의 브랜드를 상호로 동일하게 사용하고 있었고, 독자 상호는 28명(24.6\%)이었고, 유통 브랜드를 상호로 한 경우가 18 명(15.8\%), 이비인후과 부설 센터로 상호를 사용한 경우가 2명 (1.8\%)이었다. 유통 브랜드 중에는 금강, 굿모닝, 조은소리 보청 기와 같이 보청기 제조사가 직접적으로 소유한 자회사 계열도 포함되어 보청기 센터의 84명(73.7\%)은 직접적으로 보청기 제조 사와 관련이 있는 것으로 나타났다.

보청기 센터의 개설 기간에 대한 질문은 5년 미만이 30명 (26.3\%), 5년 이상 10년 미만이 28명(24.6\%), 10년 이상 15년 미 만과 15년 이상 20년 미만이 각각 19명(16.7\%)으로 동일하게 응 답하였고, 20년 이상이 18명(15.7\%)이었다(Figure 2).

보청기 센터에서 근무하는 직원을 조사하는 질문에 직원이 1명 이라고 응답한 경우가 39명(34.2\%)으로 가장 많았고, 2명인 경

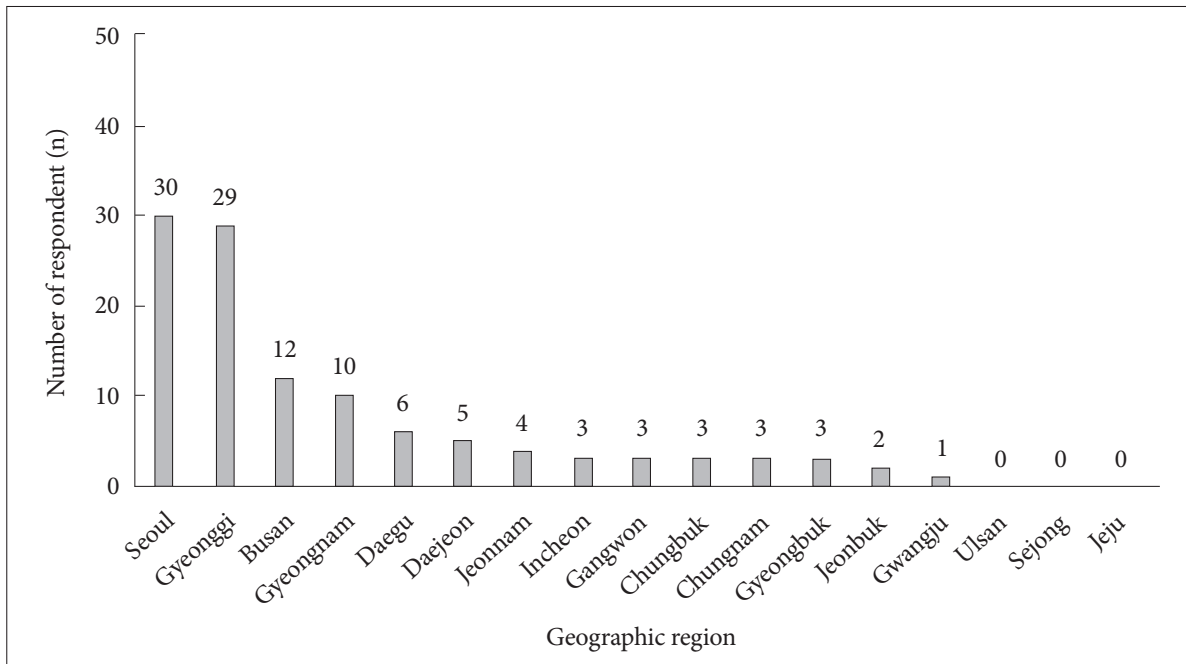

Figure 1. The geographic distribution of 114 respondents. 


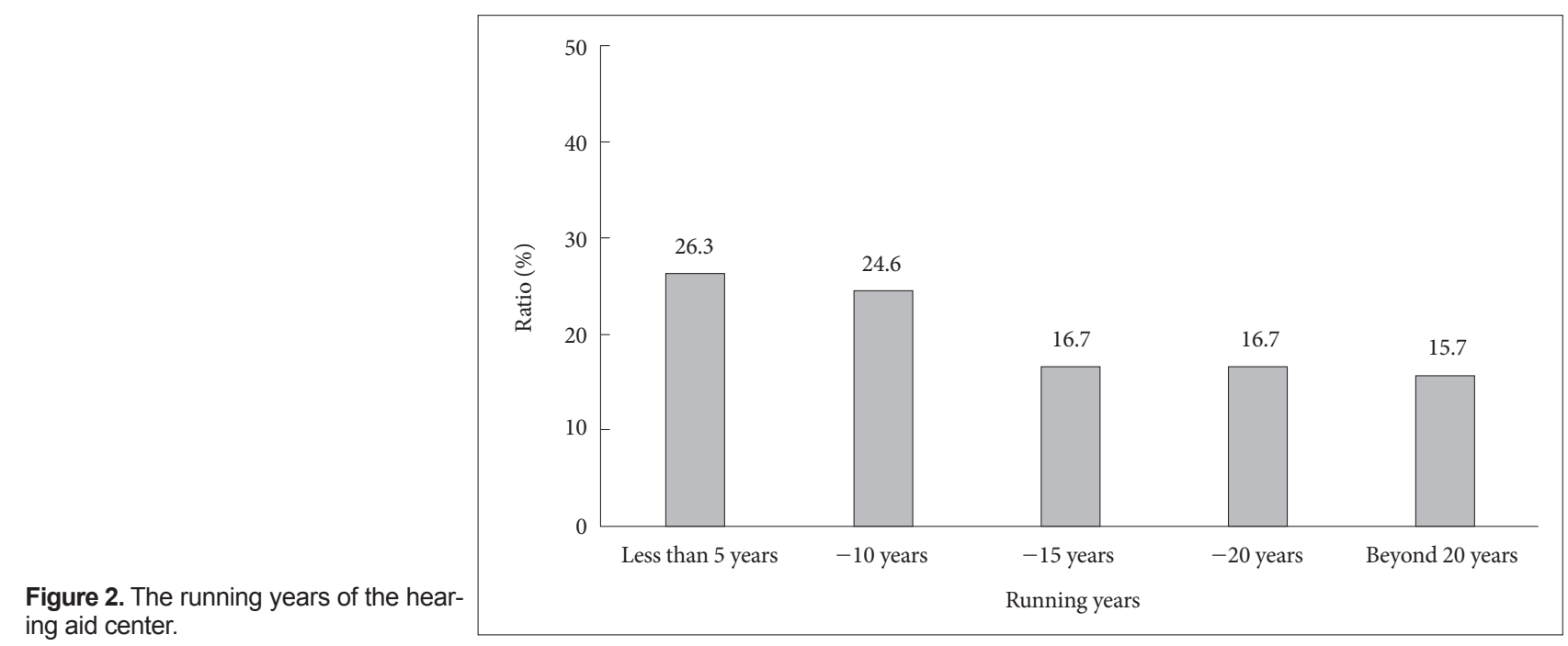

우가 22명(19.3\%), 3명인 경우는 5명(4.4\%)이었으며, 3명 이상인 경우도 14명(12.3\%)으로 조사되었고 오너 혼자 보청기 센터를 운영하는 경우는 34명(29.9\%)이었다.

\section{규모 및 시설 환경 조사}

보청기 센터의 위치에 대한 질문에 건물의 2 층이라고 답한 경 우가 40명(35.1\%)으로 가장 많았으며, 1 층이라고 답한 경우가 27명(23.7\%)이었고, 그 다음으로 3층이 22명(19.3\%), 4층이 18명 (15.8\%), 5 층 이상이 7명(6.1\%) 순으로 나타났다. 센터의 규모는 공용 면적을 제외한 실 면적(평수)을 질문하였는데, 41 명(36.0\%) 이 $82.7 \mathrm{~m}^{2}$ (25평) 이상 규모였고, 그 다음으로 $49.6 \sim 66.1 \mathrm{~m}^{2}$ (15 20평 미만)의 규모가 28명(24.6\%), 66.1 82.7 $\mathrm{m}^{2}$ (20 25평 미만)의 규모가 25명(21.9\%), 33.1 49.6 $\mathrm{m}^{2}(10 ~ 15$ 평 미만)의 규 모가 12명(10.5\%), $33.1 \mathrm{~m}^{2}(10$ 평 미만) 미만의 규모가 8명(7.0\%) 으로 나타났다. 입주 형태로는 자기 소유가 12명(10.5\%)이었으며 나머지 102명(89.5\%)이 모두 건물을 임차하고 있는 것으로 나타 났다. 임차라고 응답한 102명에게만 월 임대료 수준과 임차 보 증금에 대해 질문을 하였는데 이 중 3 명은 월 임대료 수준에 응 답하지 않았고 임차 보증금에 대한 질문도 2명이 응답하지 않 았다. 월 임대료 수준에 응답한 99명 중 관리비와 세금을 제외 하고 100만 원 미만인 경우가 27명(27.3\%)으로 가장 많았고 150 만 원에서 200만 원 미만이 26명(26.3\%), 100만 원에서 150만 원 미만이 18 명(18.2\%), 200 만 원에서 250만 원 미만이 16 명 (16.2\%)으로 나타났고, 250만 원 이상 월 임대료를 지불하는 경 우도 12명(12.1\%)으로 조사되었다. 임차 보증금에 대한 질문에 응 답한 100명 중 2,000 3,000만 원 미만으로 응답한 경우가 31명 (31.0\%)으로 가장 많았고, 4,000만 원 이상인 경우가 22명(22.0\%), 1,000 2,000만 원 미만이 18명(18.0\%), 1,000만 원 미만이 17명 (17.0\%), 3,000 4,000만 원 미만이 12명(12.0\%) 순으로 나타났다.
청력 평가와 보청기 적합을 위해 필요한 청력검사기는 112 명 (98.2\%)이 보유한다고 응답하였고 2명은 각각 실이 측정기와 보청기 분석기를 보유하고 있으나 청력검사기는 보유하고 있지 않다고 응답하였다. 청력검사기 외에 방음부스는 104명(91.2\%) 이, 보청기 분석기는 61명(53.5\%)이, 실이 측정기는 63명(55.3\%) 이 보유하고 있었다. 기타 장비로 86명(75.4\%)이 보청기를 간단 하게 수리하거나 수정(modification)할 수 있는 도구들을 구비 하고 있었으며, 비디오 오토스코프는 78명(68.4\%), 중이검사기 는 25 명 $(21.9 \%)$ 이 구비하고 있었다. 그 외는 청능 훈련 도구, 보 청기 세척용 장비, 체험용 모듈 스피커 시스템 등을 구비하고 있었다.

\section{개설 동기와 자격증 및 취급 브랜드}

가족 및 지인의 소개에 의해 센터를 개설한 경우가 43명(39.4\%) 으로 가장 많았고, 보청기 제조사에서 독립한 경우가 28명(25.7\%), 보청기 센터 또는 병원에서 독립한 경우가 12 명(11.0\%), 보청기 제조사의 대리점 모집 광고를 보고 개설한 경우가 8명(7.3\%)이 었다. 그 외 고령화에 따른 비즈니스 비전, 실버 산업의 전망, 청 각장애의 경험, 인터넷이나 매스컴 매체의 광고 등과 같은 다양 한 개설 동기로 답하였다.

보청기 센터 운영자들의 자격증과 관련 취득 학위에 대하여 중복 선택을 할 수 있는 질문에서 청능사 자격 검정원에서 주 관하는 청능사 자격증이 77명(67.5\%)으로 가장 많은 비율로 나 타났으며, 그 다음으로 한국음향학회에서 주관하는 보청기 관 리사 자격을 취득한 경우가 11 명(9.6\%)이었고, 대한이비인후과 학회의 청각사를 취득한 경우가 10 명(8.8\%)인 것으로 나타났다. 이 중 청능사와 보청기 관리사 자격을 취득한 경우가 7명, 청능 사와 청각사를 취득한 경우가 4명, 보청기 관리사와 청각사를 취득한 경우가 1 명, 세 개 자격증을 모두 취득한 경우도 1 명으 
로 나타났다. 그러나 관련 자격증이 없는 경우도 29명(25.4\%)이 있었다. 취득 학위 관련 질문에 청각학을 전공한 경우는 학사가 7명(6.1\%), 석사가 38명(33.3\%), 박사가 1명(0.9\%)이었으며, 언어 치료 석사도 3 명 $(2.6 \%)$ 이었으며, 기타 취득 학위로 다른 분야 석/박사로 응답한 경우도 1명(0.9\%)으로 나타났다.

일반적으로 보청기 센터에서는 고객의 다양한 요구에 부합 하기 위해 여러 브랜드의 제품을 취급하는 경향이 있어 주로 취급하는 브랜드, 선호 이유, 해당 브랜드에 대한 만족도 등을 조사하였다. 월 1개 이상 판매하는 보청기 브랜드를 답할 때 여 러 브랜드를 중복적으로 선택할 수 있도록 하였다. 결과는 스 타키 보청기를 취급하는 경우가 59명(52.2\%)으로 가장 많았고, 그 다음으로 지반토스 57명(50.4\%), 포낙 40명(35.4\%), 오티콘 39명(35.5\%), 와이덱스 35명(31.0\%), 벨톤 35명(31.0\%), 렉스톤 22명(19.5\%), 유니트론 16명(14.2\%), 버나폰 12명(10.6\%), 리사운 드 4명(3.5\%) 순으로 나타났다(Figure 3). 가장 많이 판매하는 브 랜드 한 개만 선택하는 질문에는 스타키 보청기가 29명 $(25.9 \%)$ 으로 가장 많았고, 지반토스 26명(23.2\%), 벨톤 15명(13.4\%), 와 이덱스 14명(12.5\%), 포낙 10명(8.9\%), 오티콘 8명(7.1\%), 렉스톤
5 명(4.5\%), 유니트론 2명(1.8\%), 버나폰 1명(0.9\%), 리사운드 1명 $(0.9 \%)$, 한사톤 1명(0.9\%)으로 나타났다.

해당 브랜드 제품을 가장 많이 판매하는 이유에 대한 질문 에는 귓속형 제품의 제조 기술을 포함한 제품의 성능이 47 명 (41.2\%), 대중적 인지도 및 마케팅이 29명(25.4\%), 소비자 만족 도가 16명(14.0\%), 공급가격이 13명(11.4\%), 다양한 제품 라인업 이 5명(4.4\%), 서비스가 3 명(2.6\%) 순으로 응답하였고 기타로 간판을 달고 있어서가 1 명 $(0.9 \%)$ 이었다. 가장 많이 판매하는 브 랜드의 전반적인 만족도를 매우 만족부터 매우 불만족까지 5 단 계로 조사하였을 때, 매우 만족은 14명(12.4\%), 만족은 65명 (57.5\%), 보통은 26명(23.0\%), 불만족은 6명(5.3\%), 매우 불만족 은 2명(1.8\%)으로 나타나 매우 만족과 만족을 합한 만족 비율 은 69.8\%였다(Figure 4). 취급 브랜드의 개선할 점에 관한 질문에 는 제품의 성능이 36명(32.1\%), 인지도 및 브랜드가 33명(29.5\%), 공급가격이 18 명(16.1\%), 서비스가 11 명(9.8\%), 다양한 제품 라 인업이 7명(6.3\%), 소비자 만족도가 6명(5.4\%) 순으로 나타났고 기타로 파트너십이 1 명 $(0.9 \%)$ 이었다.
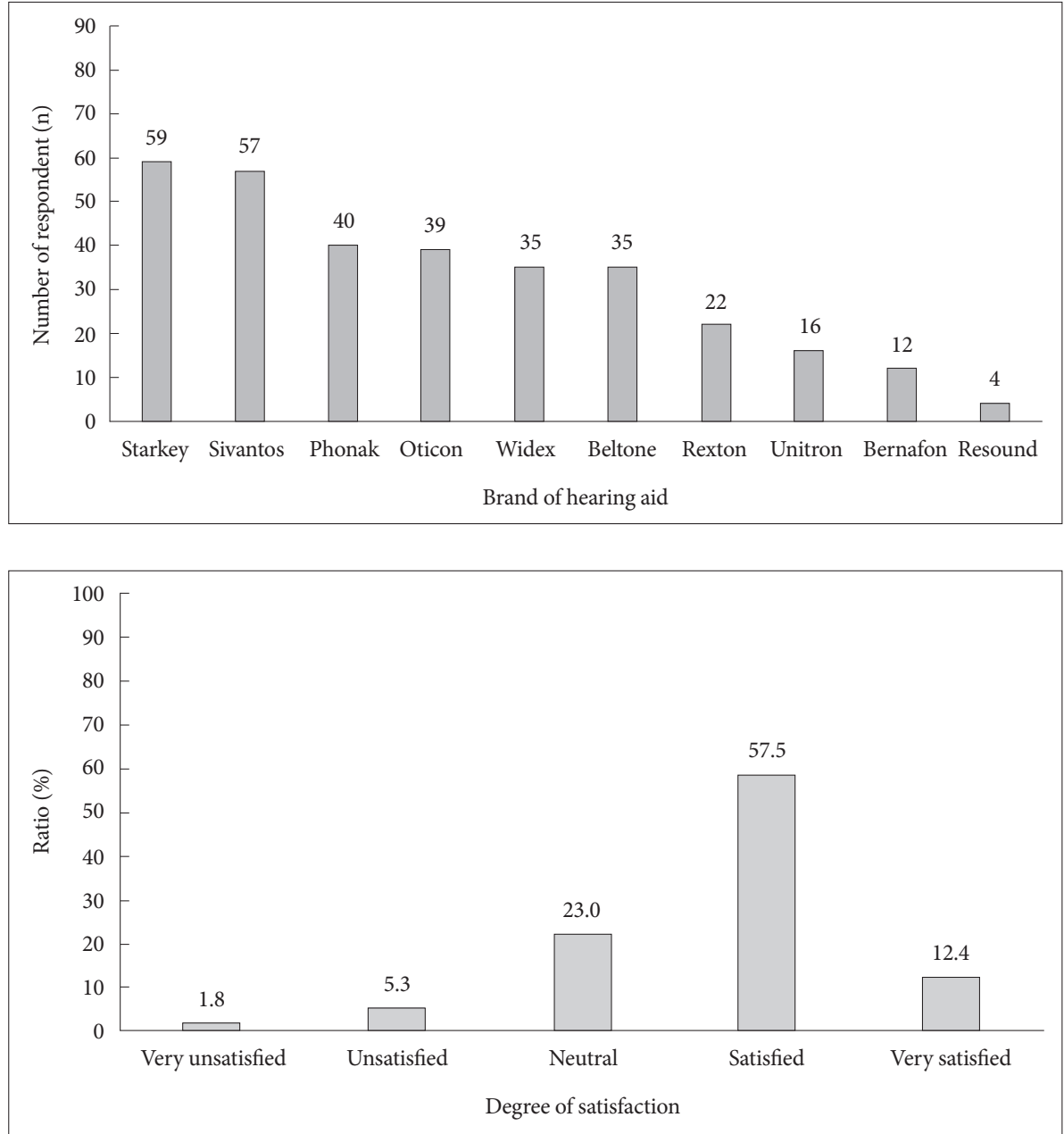

Figure 3. The number of respondents depending on kinds of hearing aid brands.
Figure 4. The ratios of satisfaction rate of the handling hearing aid manufacturers. 


\section{판매 현황 및 가격대 조사}

보청기 센터의 월 평균 판매 대수는 10대 미만이 39명(34.2\%) 으로 가장 많았고, 10 15대 미만이 34명(29.8\%), 25대 이상이 24명(21.1\%), 15 20대 미만이 9명(7.9\%), 20 25대 미만이 8명 (7.0\%) 순으로 나타났다. 보청기 한 대당 실제 고객에게 판매하 는 평균 가격은 100 150만 원 미만이 64명(56.1\%), 150 200만 원 미만이 33명(28.9\%), 200 250만 원 미만이 11명(9.6\%), 250 만 원 이상이 4명(3.5\%), 100만 원 미만이 2명(1.8\%)으로 답하였 다. 평균적인 보청기 판매 할인율은 38 명 $(33.6 \%)$ 이 권장 소비자 가격의 $50 \%$ 의 할인율을 적용한다고 응답하였으며, $30 \%$ 할인 율을 적용하는 경우가 36 명 $(31.9 \%), 40 \%$ 할인율을 적용하는 경 우가 30명(26.5\%), 60\% 할인율을 적용하는 경우가 7명(6.2\%), $60 \%$ 초과 할인율을 적용하는 경우가 2명(1.8\%)으로 나타났다.

월 평균 보청기 판매 금액은 1,500 만 원 미만이 40 명(35.7\%) 으로 가장 많았으며, 3,500만 원 이상이 26명(23.2\%), 1,500 2,000만 원 미만이 22명(19.6\%), 2,000 2,500만 원 미만이 12명 (10.7\%), 2,500 3,000만 원 미만과 3,000 3,500만 원 미만이 각 각 6명(5.4\%)씩으로 나타났다(Figure 5).

귓속형 보청기의 판매 비율에 대한 질문에 $80 \%$ 이상이 40 명 (35.1\%), $40 \%$ 미만이 29명(25.4\%), $70 \%$ 가 20명(17.5\%), 50\%가 15 명(13.2\%), 60\%가 10명(8.8\%)으로 나타났다. 귓속형 보청기 의 구체적인 형태로는 고막형이 73 명(64.6\%), 외이도형이 34명 (30.1\%), 초소형 고막형이 4명(3.5\%), 외이형이 2명(1.8\%)이었다.

보청기를 양이로 판매하는 비율이 $50 \%$ 이상으로 답한 경우 가 37 명(33.3\%)으로 가장 높았고, $30 \%$ 인 경우가 24명(21.6\%), $20 \%$ 인 경우가 21명(18.9\%), $40 \%$ 인 경우가 19 명(17.1\%), $10 \%$ 이 상인 경우가 10명 $(9.0 \%)$ 순으로 나타났다.

\section{홍보 및 마케팅}

보청기 센터의 홍보 방법은 오프라인 매체로 현수막이 45 명
(46.9\%), 전단지가 30 명(31.3\%), 신문 광고는 23명(24.0\%), 버스 및 지하철 광고가 12명(12.5\%), TV 및 라디오 광고가 10명 (10.4\%) 순으로 나타났고 그 외로 오프라인 광고를 하지 않는 센터가 10명(10.4\%)으로 나타났다. 기타로 114 우선안내와 지인 의 소개가 각각 2 명(2.1\%)으로 나타났다. 매체에 지불하는 홍보 비의 월 평균 비용은 57명(54.8\%)이 월 50만 원 미만이었고 50 100 만 원 미만인 경우가 16명(15.4\%), 200 250만 원 미만이 13명 (12.5\%), 150 200만 원 미만이 10명(9.6\%), 100 150만 원 미만 이 8 명 $(7.7 \%)$ 으로 나타났다. 온라인 홍보 매체를 이용한 방법은 블로그나 카페 활동이 68명(70.1\%), 키워드 및 배너 광고가 52명 (53.1\%), SNS가 19명(19.4\%), 온라인 기사는 16명(16.3\%), 메일 링이 3명 $3.1 \%)$ 순이었다. 홍보비로 지불한 비용은 50 만 원 미만 이 61명(58.7\%), 50 100만 원 미만이 17명(16.3\%), 200만 원 이상 이 13명(12.5\%), 150 200만 원 미만이 7명(6.7\%), 100 150만 원 미만이 6명(5.8\%) 순으로 나타났다.

\section{국내 보청기 시장의 성장에 대한 견해}

국내 보청기 시장의 성장을 저해하는 요소에 대하여 중복적 으로 선택을 할 수 있었는데, 응답 결과는 센터 간의 과열된 가 격 경쟁이 84명(75.0\%)으로 가장 많았고, 허술한 판매 자격 요건 (국가 또는 공인 자격증의 부재)이 69명(61.6\%), 제조업체의 무분 별한 유통채널 확대가 64명(57.1\%), 소비자의 난청에 대한 부정 적 인식이 46명(41.1\%), 대형 유통채널의 보청기 시장 진입 45명 (40.2\%), 이비인후과와의 마찰이 44 명(39.3\%), 보청기 관련 인허 가 및 규제가 12 명(10.7\%). 낮은 보청기 구매 보조금이 9명(8.0\%) 순으로 나타났다.

마지막으로 국내 보청기 시장이 활성화되고 성장하기 위해서 필요한 사항에 대한 질문에 중복 선택이 가능하였는데, 응답 결과는 보청기 판매업에 관한 국가 또는 공인 자격증의 개설이 81명(71.7\%)으로 가장 많았고, 난청 인식 개선 사업이 57명

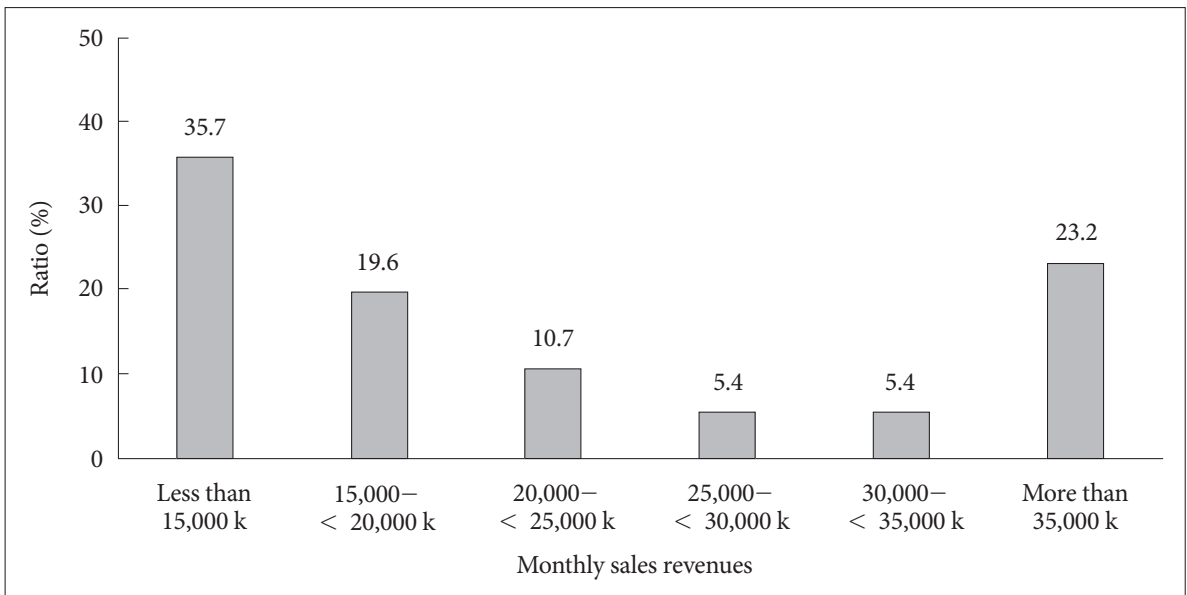


(50.4\%), 보청기 구매 지원의 의료보험화가 51명(45.1\%), 보청기 보조금 지원 확대가 36 명(31.9\%), 보청기 소비자 가격 인하가 29 명(25.7\%), 보청기 판매 관련 인허가 완화가 10명(8.8\%), 보청기 취급 채널의 확대가 2명(1.8\%)으로 나타났다.

\section{DISCUSSIONS}

본 연구는 온라인을 통한 설문조사로 개인정보 식별이 불가 능하고 익명성이 보장됨에도 불구하고 센터의 규모, 보증금, 월 매출 현황과 같이 보청기 센터에서 응답하기를 꺼려하는 민감 한 사항에 대한 설문 내용을 포함하고 있어 대상자를 모집하는 데 어려움이 있었다. 또한 온라인 설문조사의 특성상 대상군을 우리나라의 지역별 인구 분포인 경기, 서울, 부산, 경남, 인천, 대구 순으로(MIS, 2019) 동일한 비율로 맞추기는 어려웠으나 응답자의 분포는 서울, 경기, 부산, 경남, 대구 순으로 유사하게 나타났다. 그러나 장애인보장구 등록 업소의 분포 비율인 서울, 경기, 충남, 부산, 인천 순(NHISS, 2018)과는 차이를 보였다.

보청기 센터의 시설 현황에서 1 층과 2 층에 센터가 위치한 경 우가 58.8\%로 절반 이상의 보청기 센터는 입지 조건에서 주요한 고객인 노인의 접근성을 고려하고 있는 것으로 나타났다. 노인 은 이동 동선 및 건축물의 접근 용이성에서 거의 장애인에 준하 는 편의성이 요구된다는(Cha et al., 2007; Lee \& Kim, 2008) 선 행 연구의 내용과 비교할 때 절반 이상의 보청기 센터가 1 층과 2 층에 위치한 것은 노인의 접근성을 고려한 것으로 생각된다.

Gelfand(2009)는 보청기 적합은 기본적으로 청각에 대한 전 문적 지식, 보청기에 대한 전기 전자 및 물리학적 이해, 난청 및 장애에 대한 심리적인 부분까지 다룰 수 있는 전문성을 필요로 한다고 하였다. 2013년에 수립된 국가직무능력표준(National Competency Standards) 보고서에 따르면 약 5,400명이 국내 청 각 관련 산업에 종사하는 것으로 추정하고 있으며(ATS, 2019), 2018년을 기준으로 2,663명의 청능사가 등록되어 종사자의 약 $1 / 2$ 미만이 전문적인 교육을 받고 관련 자격증을 획득한 것으 로 나타났다(KAA, 2018). 고령화에 따른 난청 인구의 급속한 증가를 고려할 때 청각 관련 전문 교육을 이수한 고급 인력의 양성과 배출이 더 필요할 것으로 생각된다.

교육과 경험을 통해 습득된 전문성을 보청기 착용자에게 올 바르게 적용하기 위해서는 청력손실의 평가와 보청기 적합 과 정에서 보청기 분석기나 실이 측정기와 같은 전문 장비가 필요 하다. 본 연구에서 이와 관련하여 장비 보유 현황에 대하여 조 사하였는데 보청기 센터 중 $61.9 \%$ 가 보청기 분석기나 실이 측 정기를 보유한 것으로 나타나 보청기 센터들이 전문적인 서비 스를 제공하기 위해 어느 정도 필요한 장비를 보유하고 있는 것 으로 나타났다. 전문 교육 과정이 장비 보유 수준에 영향을 미
치는지 확인하기 위해 자격증과 장비 보유 현황에 대해 분석하 였을 때 청능사, 보청기 관리사, 청각사 자격증을 보유한 대상 자 $74.6 \%$ 의 대상자 중 전문 장비를 보유한 경우가 $65.9 \%$, 자격 증을 보유하지 않은 대상자 중 전문 장비를 보유한 경우가 $44.8 \%$ 로 전문적인 교육을 받은 경우 전문 장비를 더 많이 보유 하는 경향이 있는 것으로 나타났다. 따라서 교육이 전문적인 서 비스를 제공할 수 있는 기반이 되는 장비 보유 비율에도 영향을 끼친다고 해석할 수 있다.

국내 보청기 센터의 유형은 보청기 제조회사의 상호를 그대로 사용하거나 보청기 제조회사의 유통회사 브랜드인 경우가 84명 (74.3\%)으로 가장 많은 비율을 차지하였고, 모든 보청기 센터는 6대 보청기 브랜드로 알려진 리사운드, 오티콘, 와이덱스, 스타 키, 지반토스, 포낙 보청기의 제품 중 하나 또는 그 이상의 브랜 드를 취급하는 것으로 조사되었다. 이러한 경향은 전 세계 보청 기 시장의 $80 \%$ 이상을 6대 보청기 제조회사가 차지한다는 보 고와 보청기 제조회사들이 소매 유통 체인을 다수 소유하고 있 는 세계적인 경향과 다르지 않다고 할 수 있다(Abram, 2019).

국내에서 판매되는 보청기는 18 만 대로 추정하고 있다(Choi, 2017). 따라서 이 추정치를 보청기를 취급하는 전체 장애인보장 구 등록업소의 수인 3,089 개소로 계산하면 월 4.9개 정도를 판 매하는 것으로, 1,587 개의 보청기 센터를 기준으로 계산하면 월 9.5대 정도를 판매하는 것으로 추정이 가능하다. 월 10대 미만 을 판매하는 센터가 $34.5 \%$ 로 가장 많은 응답 비율을 보인 본 연구 결과와 일치한다. 일본은 전체 보청기 취급 업체를 기준으 로 월 6.1개 정도, 보청기 센터를 기준으로 월 12.5 개 정도의 판 매량을 보고하였고(JHIMA, 2015), 미국은 국가보훈처(veterans affairs)에서 구매하여 제공하는 보청기 판매 수량이 전체의 약 $20 \%$ 를 차지하는데, 이를 제외하고 계산하면 센터당 월 19.5개 정도의 판매량을 추정할 수 있다(Staab, 2015). 이러한 결과를 볼 때 국내 보청기 센터의 월 평균 보청기 판매 수량은 일본이 나 미국에 비해 적은 것으로 나타났다.

보청기 가격대에 대한 조사에서는 100 150만 원 미만이 56.6\% 로 절반 이상을 차지하였는데, 일본은 US\$ 880 US\$ 1,760 가 가 장 많은 $42 \%$ 비율을 차지해 국내와 비슷한 경향을 보였으나 미국은 US\$2,372로 일본이나 우리나라에 비해서 월등히 높게 보고하였다(Strom, 2018). 이는 아마도 나라별로 보청기 구매 경향이 다르기 때문인 것으로 생각된다. 예를 들어 미국의 보청 기 착용자들은 고급 기능의 보청기를 선호하는 반면 일본과 국 내 보청기 착용자는 저렴한 기본 기능의 보청기를 선호하는 경 향을 나타냈다(JHIMA, 2015; Strom, 2018). 이러한 현상은 보 청기 만족도에도 영향을 끼치는데 고급 기능을 갖춘 가격대가 높은 보청기가 주로 판매되는 미국은 보청기 만족도가 $81 \%$ 인 반면 가격대가 낮은 기본형 보청기가 주로 판매되는 일본이나 
우리나라의 보청기 만족도는 39\%(JHIMA, 2018)와 60.8\% (Chang et al., 2014)로 더 낮은 보청기 만족도를 보였다. 보청기 만족도는 보청기 성능이 가장 크게 영향을 준다는 여러 연구자 들의 보고와 일치하는 현상으로 생각할 수 있다(Abrams \& Kihm, 2015; Wong et al., 2009). 그러나 우리나라와 일본의 보 청기 만족도를 비교할 때 우리나라의 보청기 만족도가 더 높게 나타나, 양 국가 모두 저렴한 보청기를 선호함에도 불구하고 우 리나라의 보청기 관련 서비스의 수준이 높은 것으로 추정된다. 이와 같은 서비스 수준의 차이가 발생되는 주요한 원인은 일본 의 경우 언어치료와 통합된 교육 과정을 받고 언어치료와 병행 하여 청각 전문가로 활동하고 있다. 더욱이 그중 단지 $19 \%$ 만이 청각 전문가로 활동하고 있어 전문성이 독립적으로 인정되지 않는 반면 우리나라는 독립적으로 청각 분야의 전문 교육이 실 시되고 있고 따라서 자격증 체계가 확립되어 있기 때문인 것으 로 생각된다(Lee, 2006).

본 연구의 보청기 착용 형태에 관한 응답 결과는 귓속형 보 청기의 비율이 귀걸이형보다 높은 것은 선행 연구와 동일하였 지만 구체적 형태에는 차이점이 있었다. 본 연구에서는 고막형 이 $64.6 \%$ 로 가장 많았으며 외이도형이 $30.1 \%$ 로 그 다음 순으 로 나타났다. 그러나 전국 12 개 대학병원의 이비인후과를 방문 한 보청기 착용자를 대상으로 한 조사(Ahn, 2010)와 4개의 보 청기 제조사의 생산 현황을 파악한 연구에서는(Lee, 2010) 외 이도형 보청기를 가장 많이 착용하고 있고 그 다음으로 고막형 을 착용하고 있다고 보고하였다. 선행 연구와 본 연구의 결과가 다른 원인은 첫째로 보청기의 기술 개발로 인한 성능 개선이 이 전 연구들과 다른 결과를 나타낸 것으로 보인다. 최근 여러 보 청기 제조사에서는 음향 이득과 출력이 강화된 고출력의 고막 형 제품이 출시되어 고도난청자도 미관적으로 눈에 띄지 않는 소형 귓속형 제품을 착용할 수 있도록 기술 개발이 이루어졌기 때문이다. 즉, 낮은 출력이나 음향 되울림의 걱정 없이 기존 일 반 귓속형 보청기 대상자에게 고출력 고막형 보청기를 사용할 수 있고 무선 리모콘이나 어플리케이션을 통해 볼륨과 조절 범 위가 다양해져서 성능을 향상시키면서도 보청기의 사이즈를 줄 일 수 있기 때문이다. 또한 연구의 방법 중 대상자의 차이도 생 각할 수 있는데 Ahn(2010)의 연구는 이비인후과 내원 보청기 착용자를 대상으로 하였고, Lee(2010)의 연구는 보청기 제조회 사의 생산 현황을 대상으로 하였으며, 본 연구는 보청기 센터를 주 대상으로 하였기 때문에 나타날 수 있는 차이로도 생각할 수 있다.

양이 착용의 비율은 보청기 만족도에도 영향을 주는 요인 중 하나인데 보청기의 양이 착용은 소음 속 청취 능력의 향상, 소 리의 방향성 변별력 증가, 두영 효과의 감소, 이명 감소 등의 영 향으로 편측 착용에 비해 높은 만족도를 주는 것으로 보고하
였다(Schilder et al., 2017). 미국의 경우 보청기 착용자 10명 중 8 명이 양이 착용하여 약 $80 \%$ 가 양이 착용을 하는 것으로 파악 되었으나, 일본의 경우 $46 \%$ 이고 우리나라는 그보다 더 낮은 $20 \%$ 내외로 보고하였다(Abrams \& Kihm, 2015; Ahn, 2010; JHI$\mathrm{MA}, 2018)$. 그러나 본 연구 결과는 양이 판매 비율이 $50 \%$ 이 상이라고 응답한 경우가 $33.6 \%$ 로 가장 많이 나타나 이전 보고 와 비교할 때 양이 착용 비율이 증가되고 있는 것으로 생각되 며 아마도 이에 따른 보청기 만족도도 상승되었을 것으로 추측 되어 이 부분에 대해 향후 더 세부적인 조사가 필요한 것으로 생각된다.

국내 보청기 시장의 발전을 저해하는 요소와 활성화 및 성장 을 위해 필요한 요소에 대한 범주에서 두 질문에 대해 모두 보 청기 판매에 관한 자격증이 필요하다는 의견이 $61.6 \%$ 와 $71.7 \%$ 로 다른 요소보다 높은 비율을 차지하는 것으로 나타나 현재의 등록된 민간 자격증이 국가나 공인 자격증으로 좀 더 향상된 자격 요건을 바라고 있으며, 청각 전문가로서 자격증을 받기 위 한 교육의 필요성도 인식하고 있는 것으로 나타났다.

본 연구는 일부 제조회사의 대리점, 한국보청기협회 회원사 및 저자들과 연락이 닿는 보청기 센터를 대상으로 설문조사하 여 국내 시장 전체를 대변하기에는 조사의 한계성이 있다. 그러 나 국내에서 보청기 센터를 대상으로 보청기 시장 현황을 구체 적으로 이해하고 파악하려 하였으며 국내 보청기 센터의 시장 을 가늠하는 객관적 지표의 기초를 마련하고자 하였다. 향후 지 속적인 관심과 협조로 보청기 만족도를 포함한 광범위하고 세 부적인 보청기 시장 관련 연구조사가 필요할 것으로 생각된다.

중심 단어 : 보청기·보청기 센터·보청기 자격증·보청기 시장.

\section{Ethical Statement}

This study was approved by the Institutional Review Board of Hallym University (IRB \#HIRB-2018-048).

\section{Acknowledgments}

N/A

\section{Declaration of Conflicting Interests}

There are no conflict interests.

\section{Funding}

N/A

\section{Author Contributions}

All authors contributed equally to this work. S.S. and J.K. designed and performed experiments, analyzed data, and wrote the paper; S.S. designed and performed experiments in the clinic; J.K. and S.S. provided statistical analysis and critical revision; Also, the authors discussed the results together and implications and commented on the manuscript at each stage.

\section{ORCID iDs}

Sangik Sim Jinsook Kim
https://orcid.org/0000-0002-3345-299X https://orcid.org/0000-0003-3440-2393 


\section{REFERENCES}

Abram, B. (2019, April 17). Best Hearing Aid Brands in 2019: Top Hearing Aid Manufacturers. Hearing Tracker. Retrieved from https://www.hearingtracker.com/best-hearing-aid-brands.

Abrams, H. B. \& Kihm, J. (2015). An introduction to MarkeTrak IX: A new baseline for the hearing aid market. Hearing Review, 22(6), 16.

Ahn, J. H. (2010, December 31). Analysis of Obstacle and Benefit of Hearing Aid Usage of Hearing Impaired Patient. National Evidence-Based Healthcare Collaborating Agency. Retrieved from pomacis.nl.go.kr/upload/ nl/311767/ 20170410/UMO20150165179.pdf.

ATS. (2019). The Need for the System of Audiological Certificate. Audiological Testing Service. Retrieved from http://www.audiologykorea.or.kr/.

BAI. (2018, December 19). Support Status of the Next-Generation Poor. The Board of Audit and Inspection of Korea. Retrieved from https://www. bai.go.kr/bai/cop/bbs/detailBoardArticle.do?mdex=bai20\&bbsId=BB SMSTR_100000000009\&nttId=122827.

Cha, J. O., Kim, M. G., \& Park, Y. H. (2007). A comparative study on the architectural design guideline for the disabled and the aged considering accessibility and usability. Journal of the Architectural Institute of Korea Planning and Design, 23(6), 25-32

Chang, Y. S., Choi, J., Park, G. Y., Youm, H. Y., Byun, H. Y., \& Cho, Y. S. (2014). Evaluation of satisfaction with hearing aids using a questionnaire based on MarkeTrak survey. Korean Journal of Otorhinolaryngology-Head and Neck Surgery, 57(5), 304-313.

Choi, C. H. (2017). Hearing aid standardization status and industry trend, Korean agency for technology and standards. Vol. 103. Eumseong, KATS Standard Policy Division.

EHIMA. (2019). EuroTrak Country Market Surveys. European Hearing Instrument Manufacturers Association. Retrieved from https://www.ehima.com/eurotrak/.

Gelfand, S. A. (2009). Essentials of Audiology. (3rd ed.). New York, NY: Thieme Medical Publishers.

JHIMA. (2018). The Statistics of Domestic Hearing Aid Sales Report in 2017. Japan Hearing Instrument Manufacturers Association. Retrieved from http://www.hochouki.com/information/20180131-59/.

KAA. (2018). Discussions on How to Improve Audiological Services through Introduction of National Qualifications System. Seoul: The Korean Association of Audiologists.

KCDC. (2014, January 3). 5th National Health and Nutrition Assessment. Korea Centers for Disease Control \& Prevention. Retrieved from https:// knhanes.cdc.go.kr/knhanes/sub03/sub03_06_02.do.
KEIT. (2019, January 3). KEIT Supported Hallym University of Graduate Studies, Hearing Aid Related National Standard. Korea Evaluation Institute of Industrial Technology. Retrieved from https://www.keit. re.kr/articles.do?psStep=view\&bbsCD=bodo_bor\&BIdx=115784.

KHIDI. (2015, July 31). Hearing Aids Domestic and Overseas Market Analysis. Medical Device Market Research Report Vol. 34. Korea Health Industry Development Institute. Retrieved from http://www.bizhospital. co.kr/lib/download.php?tbn=special\&no=304\&PHPSESSID $=\mathrm{dc} 820 \mathrm{~d}$ 85b5ec8c6d175c2d11a9dc12f1.

KOSIS. (2017). Population Estimation by Sex and Age. Korean Statistical Information Service. Retrieved from http://kosis.kr/statHtml/statHtml. do?orgId=101\&tblId=DT_1BPA001\&vw_cd $=\& l i s t \_i d=\& s e q N o=\&$ lang_mode $=$ ko\&language $=$ kor\&obj_var_id $=\& i t m \_i d=\&$ conn_path $=$.

Lee, D. H. \& Kim, U. (2008). A study on the analysis of the accessibility elements of seniors: Focused on environment and facilities around the subway stations. Journal of Korea Intitute of Spatial Design, 3(2), 9-20.

Lee, M. S. (2006). Audiologists and the current status of audiology in Asia. Audiology and Speech Research, 2(1), 17-21.

Lee, S. Y. (2010). Proceedings from 13th Korean Academy of Audiology Conference: Selling Report of Korean Hearing Aid in 2009. Gwangju, Chunnam: Nambu University.

MIS. (2019, June). The Statistics of Registered Population. Ministry of the Interior and Safety. Retrieved from http://27.101.213.4/

MOHW. (2012, April 15). 40\% of Cochlear Implant Patients Under 9 Years Old-3,351 Cochlear Implant Surgeries Since 2005. Ministry of Health and Welfare. Retrieved from http://www.mohw.go.kr/react/al/sal0301vw. jsp?PAR_MENU_ID=04\&MENU_ID=0403\&CONT_SEQ=251105\& page $=90$.

NHISS. (2018). The Status of Registered Assistant Device Companies for the Disabled. National Health and Insurance Sharing Service. Retrieved from https://nhiss.nhis.or.kr/bd/ay/bdaya001iv.do.

Schilder, A. G., Chong, L. Y., Ftouh, S., \& Burton, M. J. (2017). Bilateral versus unilateral hearing aids for bilateral hearing impairment in adults. Cochrane Database of Systematic Reviews, 12, CD012665.

Staab, W. J. (2015). The independent hearing aid dispenser. Hearing Review, 22(9), 10.

Strom, K. (2018). Will Hearing Aid Sales Top 4 Million Units in 2018? Hearing Review. Retrieved from http://www.hearingreview.com/2018/11/willhearing-aid-sales-top-4-million-units-2018/.

Wong, L. L., Hickson, L., \& McPherson, B. (2009). Satisfaction with hearing aids: A consumer research perspective. International Journal of Audiology, 48(7), 405-427. 


\section{APPENDIX}

\section{보청기 만족도 조사를 위한 보청기 센터 및 시장 현황 조사}

〈보청기 센터 기본 조사 사항〉

본 세션은 응답자의 기본 사항과 보청기 센터 위치, 직원 현황, 보청기 센터 개설 경력 등에 관한 기초 내용입니다.

1. 본 설문에 응해 주시는 분의 직책은 무엇입니까?

(1) 보청기 센터 오너 (2) 보청기 센터 직원 (3) 이비인후과 의사 (4) 이비인후과 부설 보청기 센터 직원 (5) 기타:

2. 귀하의 보청기 센터는 아래 지역 중 어디에 위치하고 있습니까?

(1) 서울특별시 (2) 인천광역시 (3) 부산광역시 (4) 대구광역시 (5) 울산광역시 (6) 대전광역시 (7) 광주광역시 (8) 경기도

(9) 충청북도 (10) 충청남도 (11) 강원도 (12) 충청남도 (13) 경상북도 (14) 경상남도 (15) 전라북도 (16) 전라남도 (17) 제주도

3. 귀하의 보청기 센터 형태는 아래 중 어디에 해당합니까?

$\begin{array}{ll}\text { (1) 보청기 전문 센터 } & \text { (2) 이비인후과 내 보청기 센터 }\end{array}$

$\begin{array}{ll}\text { (3) 안경점 내 보청기 센터(shop in shop 형태) } & \text { (4) 의료기 기점 내 보청기 센터(shop in shop 형태) }\end{array}$

4. 귀하의 보청기 센터 상호는 아래 중 어디에 해당합니까?

(1) 제조회사 브랜드 대리점(제조업 허가 브랜드) $\quad$ (2) 유통회사 브랜드 대리점(예: 금강, 굿모닝, 다비치 등)
(3) 독자 상호 브랜드
(4) 이비인후과 부설 보청기 센터
(5) 기타:

5. 귀하의 보청기 센터는 개설한 지 얼마나 오래되었습니까?
(1) 5 년 미만
(2) 10년 미만
(3) 15년 미만
(4) 20 년 미만
(5) 20년 이상

6. 귀하의 보청기 센터에 근무하는 직원은 몇 명입니까?(오너 제외)
(1) 0 명(오너 혼자 운영)
(2) 1 명
(3) 2 명
(4) 3 명
(5) 3 명 이상

〈보청기 센터 규모 및 시설 환경 조사〉

본 세션은 보청기 센터의 규모, 시설 조건, 보유 장비 등에 관한 설문입니다.

7. 귀하의 보청기 센터는 몇 층에 위치하고 있습니까?
(1) 1 층
(2) 2 층
(3) 3 층
(4) 4 층
(5) 5 층 이상

8. 귀하의 보청기 센터의 면적은 대략 몇 평 정도입니까?(실평수 기준)
(1) 10 평 미만
(2) 15 평 미만
(3) 20 평 미만
(4) 25 평 미만
(5) 25 평 이상

9. 귀하의 보청기 센터 입주 형태는 어떤 방식입니까?
(1) 자가 소유
(2) 임대
(3) 기타:

※ 9번 답변이 “임대”일 경우 9-1), 9-2)로 진행한 후 10번으로, 그 외 답변은 바로 10 번으로 진행해 주세요. 9-1) 귀하의 보청기 센터의 월 임대료 수준은 어느 정도입니까?(관리비 및 세금 제외)
(1) 100 만 원 미만
(2) 150 만 원 미만
(3) 200 만 원 미만
(4) 250 만 원 미만
(5) 250 만 원 이상

9-2) 귀하의 보청기 센터 임대보증금은 어느 정도입니까?
(1) 1,000 만 원 미만
(2) 2,000 만 원 미만
(3) 3,000 만 원 미만
(4) 4,000 만 원 미만
(5) 4,000 만 원 이상 
10. 귀하의 보청기 센터에서 보유한 장비는 다음 중 어느 것입니까? 여러 개인 경우 모두 표기해 주세요.
(1) 청력검사기
(2) 보청기 분석기
(3) 실이 측정기
(4) 비디오스코프
(5) 방음 부스(인테리어형 포함)
(6) 중이검사기
(7) 수리도구(modification 가능 도구)
(8) 기타:

\section{〈보청기 센터 개설 동기 및 취급 브랜드〉}

본 세션은 보청기 센터를 개설하게 된 동기, 보유하신 자격증, 취급 보청기 브랜드 등에 대한 설문입니다.

11. 귀하께서 보청기 센터를 운영하게 된 동기는 무엇입니까?
(1) 가족 및 지인의 소개
(2) 보청기 제조업체의 광고 및 소개
(3) 제조업체 직원에서 독립
(4) 보청기 센터에서 독립
(5) 기타:

12. 귀하께서 보유하고 있는 학위나 보청기 및 청각 관련 자격증은 다음 중 어느 것입니까? 여러 개인 경우 모두 표기해 주 세요.

$\begin{array}{lll}\text { (1) 청능사(청능사 자격 검정원) } & \text { (2) 청각사(대한이비인후과학회) } & \text { (3) 보청기 관리사(한국음향학회) }\end{array}$
(4) 청각학 박사
(5) 청각학 석사
(6) 청각학 학사
(7) 관련 자격증 없음
(8) 기타:

13. 귀하께서 주로 취급하는 보청기 브랜드는 무엇입니까?(최소 월 1개 이상 판매하는 브랜드) 여러 개인 경우 모두 표기해 주세요.
(1) 스타키
(2) 지반토스
(3) 오티콘
(4) 포낙
(5) 와이덱스
(6) 리사운드
(7) 렉스톤
(8) 버나폰
(9) 유니트론
(10) 벨톤
(11) 기타:

14. 귀하의 보청기 센터 전체 매출 중 제일 높은 비중으로 취급(판매)하는 브랜드는 다음 중 어느 것입니까?
(1) 스타키
(2) 지반토스
(3) 오티콘
(4) 포낙
(5) 와이덱스
(6) 리사운드
(7) 렉스톤
(8) 버나폰
(9) 유니트론
(10) 벨톤
(11) 기타:

15. 귀하께서 제일 높은 비중으로 취급하는 브랜드를 선정한 가장 큰 이유는 무엇입니까?
(1) 제품 성능(귓속형 제조 수준 포함)
(2) 공급가격
(3) 서비스
(4) 인지도/마케팅
(5) 소비자 만족도
(6) 다양한 제품 라인업
(7) 기타:

16. 귀하께서 제일 높은 비중으로 취급하는 브랜드의 전반적인 만족도는 어느 정도입니까?
(1) 매우 불만족
(2) 불만족
(3) 보통
(4) 만족
(5) 매우 만족

17. 귀하께서 제일 높은 비중으로 취급하는 브랜드의 개선해야 할 사항은 무엇입니까?
(1) 제품 성능(귓속형 제조 수준 포함)
(2) 공급가격
(3) 서비스
(4) 인지도/마케팅
(5) 소비자 만족도
(6) 다양한 제품 라인업
(7) 기타:

\section{〈보청기 센터 판매 현황 및 가격대 조사〉}

보청기 센터별 판매 현황에 대한 기초 자료 조사입니다. 민감한 사항일 수 있으나 과표 구간으로 표시되었고 개별 정보는 식 별 불가능함을 다시 한 번 알려 드립니다. 정확한 통계 조사를 위해 최대한 솔직히 응답해 주시면 감사하겠습니다.

18. 귀하의 보청기 센터 월 평균 보청기 판매 대수는 몇 대입니까?
(1) 10 대 미만
(2) 15 대 미만
(3) 20대 미만
(4) 25 대 미만
(5) 25대 이상

19. 귀하의 보청기 센터에서 판매되는 보청기 한 대당 가격은 평균적으로 얼마입니까?(실제 판매가격 기준)
(1) 100 만 원 미만
(2) 150 만 원 미만
(3) 200 만 원 미만
(4) 250 만 원 미만
(5) 250 만 원 이상 
20. 귀하의 보청기 센터의 평균적인 보청기 판매 할인율은 어느 정도입니까?
(1) $30 \%$
(2) $40 \%$
(3) $50 \%$
(4) $60 \%$
(5) $60 \%$ 초과

21. 귀하의 보청기 센터 월 평균 총 보청기 판매 금액은 얼마입니까?
(1) 1,500 만 원 미만
(2) 2,000 만 원 미만
(3) 2,500 만 원 미만
(4) 3,000 만 원 미만
(5) 3,500 만 원 미만
(6) 3,500 만 원 이상

22. 귀하의 보청기 센터에서 판매하는 귓속형 보청기의 비중은 어느 정도입니까?
(1) $40 \%$ 미만
(2) $50 \%$
(3) $60 \%$
(4) $70 \%$
(5) $80 \%$ 이상

23. 귀하의 보청기 센터에서 주로 판매되는 귓속형 보청기 타입은 어떤 타입입니까?
(1) $\| \mathrm{C}$ (초소형 고막형)
(2) $\mathrm{CIC}$ (고막형)
(3) ITC(일반 귓속형)
(4) ITE(외이형)

24. 귀하의 보청기 센터의 양이 판매 비중은 어느 정도입니까?
(1) $10 \%$
(2) $20 \%$
(3) $30 \%$
(4) $40 \%$
(5) $50 \%$ 이상

\section{〈보청기 센터의 홍보/마케팅〉}

보청기 센터에서 주로 시행하는 홍보 및 마케팅 매체에 대한 사항입니다.

25. 귀하의 센터에서 가장 큰 비중을 두어 홍보하는 오프라인 매체는 무엇입니까?(2가지 이상 선택)
(1) 신문 광고
(2) TV/라디오 광고
(3) 전단지
(4) 현수막
(5) 버스/지하철 광고
(6) 기타:

26. 귀하의 센터에서 홍보를 위해 오프라인 매체에 지불하는 비용은 월 평균 어느 정도입니까?
(1) 50 만 원 미만
(2) 100 만 원 미만
(3) 150 만 원 미만
(4) 200 만 원 미만
(5) 250 만 원 미만

27. 아래에서 귀하의 센터에서 가장 비중을 두어 홍보하는 온라인 매체는 무엇입니까?(2가지 이상 선택)
(1) 키워드/배너 광고
(2) 블로그/카페 광고
(3) SNS(페이스북, 카카오스토리 등)
(4) 온라인 기사
(5) 메일링
(6) 기타:

28. 귀하의 센터에서 홍보를 위해 온라인 매체에 지불하는 비용은 월 평균 어느 정도입니까?
(1) 50 만 원 미만
(2) 100 만 원 미만
(3) 150 만 원 미만
(4) 200 만 원 미만
(5) 250 만 원 미만

〈국내 보청기 시장의 성장에 대한 견해〉

본 세션은 현재 보청기 시장의 문제점과 향후 국내 보청기 시장에 대한 여러분의 견해를 알아보는 설문입니다.

29. 현재 국내 보청기 시장의 성장을 저해하는 요소는 다음 중 무엇이라고 생각하십니까? 여러 개인 경우 모두 표기해 주세요.
(1) 허술한 판매 자격 조건(국가/공인 자격증 부재)
(2) 센터 간 과열된 가격 경쟁
(3) 대형 유통채널의 보청기 시장 진입(예: 코스트코)
(4) 낮은 보청기 구매 보조금
(5) 이비인후과와 마찰
(6) 제조업체의 무분별한 유통채널 확대
(7) 보청기 관련 인허가 및 규제
(8) 소비자의 난청에 대한 부정적 인식

(9) 기타:

30. 향후 국내 보청기 시장이 활성화되고 성장하는 데 우선적으로 필요하다고 생각되는 사항은 다음 중 어느 것입니까? 여러 개인 경우 모두 표기해 주세요.
(1) 보청기 판매업에 대한 국가/공인 자격증 개설
(2) 보청기의 소비자 가격 인하
(3) 보청기 보조금 지원 확대
(4) 보청기 구매 지원의 의료보험화
(5) 난청 인식 개선 사업
(6) 보청기 취급 채널의 확대(유통채널)
(7) 보청기 판매 관련 인허가 완화
(8) 기타: 